\title{
Cervical myelopathy caused by ligamentum flavum ossification
}

\author{
Mielopatia cervical por ossificação do ligamento amarelo \\ Wellingson Silva Paiva', Matheus Schimidt Soares', Luca Silveira Bernardo', Roger Schimidt Brock', Manoel \\ Jacobsen Teixeira²
}

Ossification of the ligamentum flavum (OLF) is a rare manifestation and when causing myelopathy it affects essentially the thoracic spine ${ }^{1}$. Only a few cases of symptomatic cervical disease have been reported, with all patients being Japanese ${ }^{2}$. The first OLF case reported in a Caucasian was performed by Parekh et al., in 19933. Since then, 19 cases have been reported in Caucasian patients and all of them in the thoracic spine ${ }^{2}$. The authors report the first case with cervical myelopathy caused by OFL in a Caucasian patient surgically treated with a good outcome.

\section{CASE REPORT}

A 66-year-old Caucasian woman presented two months of gait disturbance, weakness of the inferior limbs and several episodes of falling down. She noticed progressive sensory loss, which ascended to the mid-thoracic level. Neurological examination of the upper and lower limbs revealed normal tone, bilateral clonus, power in the limbs was $3 / 5$ throughout and equal in all limbs, and hypereflexia in inferior limbs. She had absent sensation below T4 and bilateral ulnar three fingers and ulnar halves. There was no related trauma in her history.

A magnetic resonance image (MRI) demonstrated low signal in the region of the ligamentum flavum in T2 images from C2 to C5 (Figure). There was spinal cord compression at $\mathrm{C} 3$ to $\mathrm{C} 6$ levels, with the most severe being between $\mathrm{C} 3$ to C4. A computed tomography (CT) scan confirmed the OLF at levels C2 to C5 (Figure).

Decompressive laminectomy with removal of the ligamentum flavum from C3 to C6 was performed. In the twomonth follow-up, post-surgery examination revealed normal tone, absent clonus, return of $4 / 5$ power throughout both her four limbs and normal reflexes.

\section{DISCUSSION}

Since Polgar first reported a case of OLF in 1920 using plain lateral radiographs, most reports of thoracic myelopathy originated from Japan ${ }^{4,5}$. Cervical spine ossification is rarer, and there have been no cases reported in Caucasians. The histopathological aspects of OLF are similar to ossification posterior to

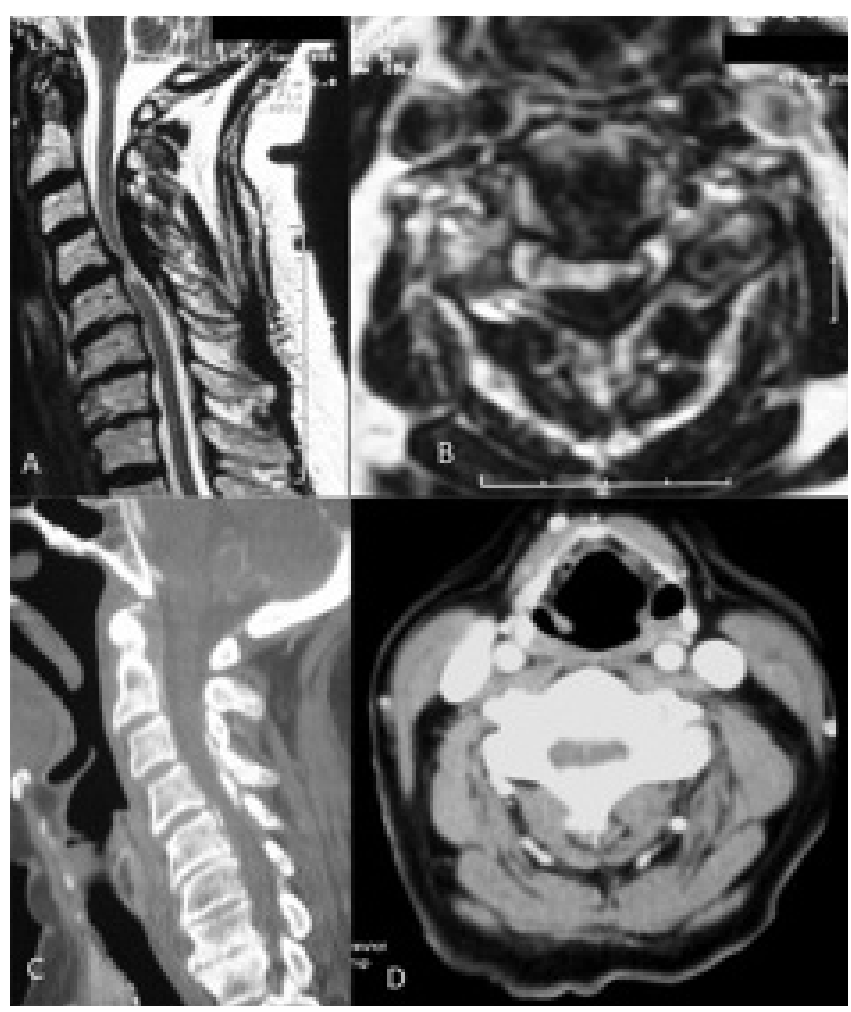

Figure. Magnetic resonance image with spinal cord hypersignal and compression. Hyposignal in ligamentum flavum indicates ossification. A - sagital slice; B - axial slice; C - sagittal; D - axial cervical spine computed tomography demonstrated hyperdense in ligamentum flavum with narrowing cervical spinal canal.

Division of Neurosurgery, Hospital das Clínicas, Medical School, University of São Paulo (USP), São Paulo SP, Brazil.

${ }^{1} \mathrm{MD}$; Staff - Division of Neurosurgery, USP, São Paulo SP, Brazil;

${ }^{2} \mathrm{MD}$, PhD; Full Professor of Neurosurgery, USP, São Paulo SP, Brazil.

Correspondence: Wellingson Paiva; Rua Eneas Aguiar 255; 05403-010 São Paulo SP - Brasil; E-mail: wellingsonpaiva@yahoo.com.br

Conflict of interest: There is no conflict of interest to declare.

Received 12 July 2011; Accepted 04 August 2011 
longitudinal ligament (OPLL) 2 . OPLL also begins with a degeneration of ligamentous fibers and is followed by endochondral ossification. This process suggests a common etiological factor; these two affections are considered to be a form of ectopic ossification. Ectopic ossifications like OLF can be caused by an increase in the concentration of fibronectin or in the concentration of bone morphogenetic protein ${ }^{4}$. Both OPLL and OLF are commonly reported in Japanese populations, raising the possibility of a genetic link between the two ${ }^{4}$. The study reported by Ono et al. ${ }^{5}$ has preliminarily indicated that abnormalities in the type XI collagen gene may be involved in spine ossification. Based on the similarities at the molecular level in the calcification process, it may be reasonable to hypothesize that a similar abnormality in a collagen gene may be the cause for OLF.

The prognosis after surgery can be good, especially if intramedullary hyperintensities are absent in preoperative $\mathrm{MRI}^{2}$. The partial improvement of the symptoms is probably due to the irreversible spinal damage caused by a long-term cord compression. The OLF presents complex physiopathology and it is rare in non-Asians.

\section{References}

1. Gondim J, Ramos Jr F. Thoracic spinal cord compression at two levels due to ligamentum flavum calcification: case report. Arq Neuropsiquiatr 1998;56:312-316.

2. Ono K, Yonenobu K, Miyamoto S, Okada K. Pathology of ossification of the posterior longitudinal ligament and ligamentum flavum. Clin Orthop Relat Res 1999;359:18-26.

3. Parekh HC, Gurusinghe NT, Perera SS, Prabhu SS. Ossification of the ligamentum flavum in a Caucasian: case report. Br J Neurosurg 1993;7:687-690.
4. Miyamoto S, Takaoka K, Yonenobu K, Ono K. Ossification of the ligamentum flavum induced by bone morphogenetic protein. An experimental study in mice. J Bone Joint Surg Br 1992;74:279-283.

5. Ono K, Yonenobu K, Miyamoto S, Okada K. Pathology of ossification of the posterior longitudinal ligament and ligamentum flavum. Clin Orthop Relat Res 1999;359:18-26. 